\title{
PRACTICE
}

\section{Business in a Liberal Arts College: Undergraduate Research Experiences That Cultivate Habits of the Heart and Mind}

\author{
Vicki L. Baker, John Carlson, \\ Albion College
}

\begin{abstract}
The authors discuss a course-based undergraduate research (UR) experience in business, seeking to continue a conversation initiated by Miller and DeLoach (2016) regarding undergraduate research in professional fields. The current state of liberal arts colleges and business education is described, as are the three modes of thinking developed by students during their UR participation. The authors also discuss lessons learned and provide insights into the components needed to support a course-based UR experience in other settings.
\end{abstract}

Keywords: business, course-based undergraduate research experiences, liberal arts colleges, undergraduate research

doi: $10.18833 /$ spur $/ 2 / 2 / 3$

In the seminal article "Seven Principles for Good Practice in Undergraduate Education," Chickering and Gamson (1989) outlined seven practices to improve teaching and learning in an undergraduate environment. They advocated for the importance of strong student-faculty relationships, the need to make learning collaborative to support active (as opposed to passive) learning pedagogies, the sharing and receiving of consistent and substantive feedback, and the development of time management skills. Chickering and Gamson also noted the significance of high expectations and supporting achievement, while appreciating (and encouraging) a diversity of learning styles. As the authors noted, "There is good evidence that such an environment can be created" (6). This statement, however, raises an important question related to these principles: How can these practices be applied in more concrete and deliberate ways as part of the undergraduate student experience? Course-based undergraduate research experiences can provide such an opportunity.

Guest editors Miller and DeLoach (2016) discussed the role of undergraduate research in the professions, the focus of a Special Issue on Mentoring Undergraduate Research in the Professional Disciplines of Perspectives on Undergraduate Research and Mentoring (PURM). In their opening letter the editors noted:

This edition of PURM likewise underscores how the practice of undergraduate research may also be a critical component for professional disciplines - ranging from business to communications to human services-as research plays an increasingly important role in preparing students for future careers and serving as a bridge between the classroom and the real-world. (para. 9)

Undergraduate research experiences are on the rise across all institutional types (Wawrzynski 2016). Whereas the sciences have been and continue to be leaders in this highimpact practice (Kuh 2008), the special issue of PURM sought to highlight undergraduate research experiences in professional fields, including business. This article seeks to add to the conversation about the importance of undergraduate research experiences in business education (Bartkus 2007; Fairfield-Doering 2013) with a description of an undergraduate research experience incorporated into a fourth-year capstone course at the Gerstacker Institute for Business and Management at Albion College. The authors, as management and accounting professors at a liberal arts college, seek to develop the habits of both the hearts and minds of students. Although neither of these disciplines is 
considered a traditional liberal arts discipline, the approach pursued in classrooms and through the use of course-based undergraduate research experiences aims to build the skills that are hallmarks of a liberal arts education.

The evolving and sometimes contentious conversation that surrounds the role of business education in a liberal arts college context is described here, including a brief historical overview. The three modes of thinking outlined by Colby and colleagues (2011) and their connection to the undergraduate research experience then are discussed. The undergraduate research (UR) capstone experience for fourth-year students is described, highlighting these three ways of thinking. Finally, lessons learned are shared, and insights into how such an experience can be emulated are provided.

\section{Liberal Arts Colleges and Business Education}

The fate and state of liberal arts colleges (LAC) continues to be press worthy, with headlines in major national publications (Belkin 2017). The focus of these articles is on the current viability of such institutions in the higher education landscape. Questions of affordability and other key metrics of success such as job placements and total enrollment dominate conversations about the sustainability of an institutional mission that seeks to educate democratic citizens versus a vocational focus aimed at training the next generation of workers.

Despite questions of relevance and return on investment, the liberal arts college education continues to serve as a model of undergraduate education domestically and abroad. Research universities and comprehensive colleges continue to imitate LACs within their institutional walls by way of honors colleges and residential living learning communities in an effort to offer small class sizes, close student-faculty relationships, and undergraduate research experiences that are the hallmark of LACs (Baker, Baldwin, and Makker 2012). More than 25 years ago, Breneman (1990) asked the provocative question, "Are we losing our liberal arts colleges?" He found that, by his definition, only 212 institutions remained that could be considered true liberal arts colleges. Baker and colleagues (2012) replicated his study and found a continued decline when applying Breneman's conceptualization. However, Baker et al. (2012) and Baker and Baldwin (2015) suggested that perhaps, rather than losing LACs, there is an evolution underway in this sector of higher education. This evolution influences what a liberal arts college education looks like in the twenty-first century, as administrators, campus leaders, and faculty members seek to reimagine experiential learning activities in this institutional context.

Business education as a field has also experienced several transformations in which the pendulum has swung between a focus on practical, vocational training to one characterized as rigorous, research based, and analytically driven (Friga, Bettis, and Sullivan 2003; Guerriero Wilson 2015). Business educators argue that, given the global economy, technological advances, and market forces, business education may experience greater change and pressure than any other branch of higher education (Friga et al. 2003).

Business education is not without its critics, who suggest that the value system promoted by a business education has not only contributed to the business scandals over the past decade but also failed to instill a sense of greater responsibility in its graduates. For example, Giacalone commented, "Our fundamental business curriculum has no higher order ideals. What ideals should our students aspire to achieve?" (2004, 416). Cavico and Mujtaba (2009) argued that business education fails to impart the needed skills and knowledge to instill the norms of ethical behavior, which has contributed to the declining reputation and ethicality of business today. Further, Starkey and Tiratsoo (2007) argued that the business school world has lost its educational soul in its quest for greed and power. Instead, what is needed are business programs that are responsive to market need; are agile; and engage business researchers, practitioners, and the local and global communities (Parker and Guthrie 2010).

Colby and colleagues (2011) discussed the adequacy of current business education and urged reevaluation of how a business education is defined, implemented, and assessed. The authors argued that most undergraduate programs are too narrow, failing to challenge students to question assumptions, think creatively, or understand the place of business in larger institutional contexts. The authors noted, "Along with preparation for responsible citizenship in a general sense, business students need to develop as civic leaders within the business domain" (163).

Colby and colleagues (2011) focused on three core liberal arts modes of thinking: analytical thinking (e.g., problem solving, applying abstract concepts in practical contexts), multiple framing (e.g., an appreciation of different perspectives for viewing the world), and reflective exploration (e.g., sense of self, contribution to the world, hopes for the future). In this article, the authors argue that these modes of thinking in the context of undergraduate business education align with the focus of a liberal arts education in developing habits of the heart and mind. Such a focus fulfills the academic goals of higher education while helping students craft meaningful and personally fulfilling lives that "are implicated in the well-being of others" (Fong 2004, 11). Business education in an LAC environment counters what Colby and colleagues (2011) described as an overreliance on one mode of thinking (analytical thinking), neglecting multiple framing and reflective exploration. Further, course-based undergraduate research 
experiences epitomize what Colby and colleagues referred to as pedagogies of enactment, defined as "explicit and intentional about representing expertise and providing practice accompanied by informative feedback" (2011, 89). In the following section, a course-based undergraduate research experience is discussed that seeks to develop the three liberal arts modes of thinking while serving as a pedagogy of enactment, as characterized by Colby and colleagues (2011).

\section{Undergraduate Research in a Fourth-Year Capstone Course}

The Gerstacker Institute Senior Capstone is a one-quarter unit (one college hour) semester-long class at Albion College designed to challenge fourth-year students to integrate their experiences and education as they solve an existing problem or generate new research. The class is designed to be project based and requires students to work as a team of consultants to analyze issues, create possible solutions, and disseminate results. The team approach is a valuable learning experience for students as a practice of collective agency (Raelin 2016), a skill desired by many employers. Further, such an approach allows each student to bring strengths to the project, gain an understanding of divergent points of view, appreciate the possibility of generating synergistic benefits, and negotiate a common ground for communicating possible solutions. The authors argue that these also are important skills for aspiring scholars. Four students were enrolled during the spring 2017 semester. All were fourth-year students who were majoring in business and organizations and were members of the Gerstacker Institute. Two students were double majors (communication studies and finance).

The students were given a short list of projects and asked, as a team, to select one after weighing the purpose, goals, and outcomes of each (analytical thinking). Perhaps more important, the aim was to obtain the individual student commitments necessary to accomplish the task and to have the students consider thoughtfully the implications of their efforts and the beneficiaries of the final result (multiple framing). Such an approach fosters a sense of ownership and personal reflection as students engage in sense-making of the broader implications of their efforts and their individual roles, as well as growth as a result of team performance (reflective exploration). The team selected a fund-raising and outreach project that addressed how to keep recent alumni connected with the college. Historically higher education institutions have asked for donations as early as commencement from graduates, but the amounts and the frequency of gifts have been low. Given that many graduates have high student loan debt (the average debt amount in 2016 was $\$ 37,172$ ), the vice president of institutional advancement was looking for some fresh ideas to enhance the relationship between the college and young alumni.
The team gathered evidence by interviewing various members of the Institutional Advancement Department and discussing prior fund-raising programs, alumni events (both on and off campus), and marketing materials and newsletters. During the semester, the team invited small groups of alumni back to campus and discussed the project with their classmates to solicit input on improving the engagement of young alumni with the college. The team decided to focus on a smaller subset of recent graduates (years 2012 through the present) and design a short (12-question) electronic survey to obtain needed data. Acknowledging that discretionary cash might be hard to come by during the first few years of the graduates' careers, the team intentionally excluded any direct or indirect request for donations. The survey was administered to 1,840 alumni, and 217 graduates responded (a response rate of 11.8 percent).

The survey requested the standard demographic information (year of graduation, major(s), current location, contact preferences, etc.) but also included the following four questions, designed to determine the degree of connection or potential connection with the college and how the college could continue to help them craft meaningful personal and professional lives:

- What groups, programs, organizations, institutes, or centers were you involved in as an undergraduate? (a response rate of 98 percent)

- What groups, programs, organizations, institutes, or centers do you continue to feel a connection to? (a response rate of 95 percent)

- Are you interested in attending events with other Albion alumni? (a response rate of 93 percent)

- How do you wish the college could help you move forward personally or professionally? (a response rate of 56 percent)

The survey produced some interesting results. Overwhelmingly the recently graduated alumni continued to be interested in the programs in which they were involved while in college, especially Greek life, athletics, and various institute-type organizations. Further, they were interested in both returning to campus and having off-campus gatherings related to those programs. Respondents also were very interested in attending career development workshops, social functions, and networking events with other Albion alumni. They encouraged the college to actively offer more networking opportunities regionally. The overriding themes of the responses to "How do you wish the college could help you move forward personally or professionally?" were the desires to stay in touch with the college and to increase networking opportunities. Alumni suggested more specific event or specific-purpose emailing (rather than generalized college email); a stronger social media presence; the desire to reconnect with faculty; and opportunities to return to 
campus and present their research, interview students, or teach a class. Most of all, the alumni were looking for additional ways to network with each other.

The team presented the survey results and their recommendations at the end of the semester to the institutional advancement team, with various members of the College Board of Trustees in attendance.

\section{Research Capabilities and Habits of Heart and Mind}

As the authors reflected on the experience, including insights from all stakeholder groups (students, alumni, faculty, and administrators), some important lessons were gleaned. First, engagement in this experience facilitated students' efforts to hone their analytical thinking, multiple framing, and reflective exploration skills through mediums beyond traditional accounting or management experiences (see Table 1 for student observations). Students were able to learn about and immerse themselves in the research process, which supported the development of analytical thinking. This included identification of a business problem for which a solution was sought. To solve that business problem, students had to think about the resources (human, financial, and physical) needed and available to achieve the desired outcome. To that end, students conducted literature reviews and analyses of best practices, developed data collection tools and pilot tested those tools, administered data collection tools, cleaned and analyzed data, and disseminated results to key college stakeholder groups. The approach to this undergraduate research experience aligned with the best practices outlined by Hensel (2012) in CUR's Characteristics of Excellence in Undergraduate Research.
Second, through multiple framing, students learned about the importance of developing partnerships on and off campus to ensure a greater likelihood of maintaining connections between the college and recent graduates. Given that these four fourth-year students were soon to be graduates, they were able to make this business problem more personally meaningful and view it through the eyes of others. Insights gleaned from the survey were of particular import to staff members of the Gerstacker Institute and were the focus of a post-experience debriefing. One immediate action item, on the agenda for the coming academic year, is the development of a more strategic effort to engage young alumni. As the Gerstacker Institute director noted:

We will now look at connecting young alumni not only by location but also by field when possible (with both young and seasoned alumni). There [also] seemed to be a high desire for continuing to expand alumni networks within their fields or in fields of interest outside their current employment

The authors particularly appreciate that this outcome serves as a good reminder to all those interested in supporting undergraduate research experiences of the important role of reflective exploration beyond the classroom setting. As a result of participation in the fourth-year capstone, the four students gained a greater appreciation of their personal and professional development and of how they can support the college's efforts moving forward.

It is important to note that this experience would not have been possible without the business problem posed by institutional advancement, the structure provided by the fourthyear capstone experience, the faculty member(s) willing

TABLE 1. Student Reflections on Fourth-Year Capstone Experience

\begin{tabular}{|c|c|c|}
\hline Analytical thinking & Multiple framing & Reflective exploration \\
\hline $\begin{array}{l}\text { "My team and I thought that this [fund- } \\
\text { raising] would be a manageable project but } \\
\text { we soon learned that there were so many } \\
\text { different opportunities for a project within } \\
\text { fund-raising that we didn't know where to } \\
\text { start, it was very overwhelming." } \\
\text { "We started to break down the overall } \\
\text { project of fund-raising into smaller segments } \\
\text { that could make feasible projects, and could } \\
\text { be completed within the 14-week semester." } \\
\text { "This was still too big of a project so we } \\
\text { narrowed it even further and decided to } \\
\text { look only at recent alumni (1-5 years out of } \\
\text { school). We wanted to focus on recent } \\
\text { alumni as we would know many of these } \\
\text { people and hopefully they would be more } \\
\text { willing to work with us." }\end{array}$ & $\begin{array}{l}\text { "We started by saying we wanted to work } \\
\text { with alumni with similar and different inter- } \\
\text { ests from us, that way we could understand } \\
\text { their college experience and use that to draw } \\
\text { interest in donating money and engaging with } \\
\text { the school." } \\
\text { "We settled on trying to improve their rela- } \\
\text { tions with the college so they would be more } \\
\text { willing to engage with the College as recent } \\
\text { graduates and donate in the future." } \\
\text { "We recognized that there are many financial } \\
\text { obstacles (student loans, first house, starting } \\
\text { a family, etc.) that limit the money available } \\
\text { to donate to Albion. But we realized, through } \\
\text { this research, that there are other ways to } \\
\text { engage alumni with the College that aren't } \\
\text { financially motivated." }\end{array}$ & $\begin{array}{l}\text { "This project was also something I used on } \\
\text { my resume and it helped me get my first } \\
\text { job." } \\
\text { "I walked away from this project feeling } \\
\text { good about the work we provided to the } \\
\text { College. And, it allowed me to engage with } \\
\text { others who feel a sense of pride about Albion } \\
\text { College. This project allowed us to take a } \\
\text { step back and see the bigger picture." } \\
\text { "The ability of narrowing down a project into } \\
\text { something manageable is a skill that I will } \\
\text { take with me into the work force and will } \\
\text { allow me to work on even the biggest project } \\
\text { without getting overwhelmed." }\end{array}$ \\
\hline
\end{tabular}


to facilitate the experience, and the alumni committed to supporting the college and student learning. Additionally, rather than treat this experience as just another class-based activity, students met with key stakeholder groups to discuss the implications of their efforts and how the findings may be acted on in the future. Liberally educated students are concerned about improving the communities in which they have membership. This experience reinforced that message by illustrating the power of campus and community partnerships and their role in course-based undergraduate research experiences.

Finally, a powerful reflection surfaced as part of the post-experience debriefing. In conversation with the Gerstacker Institute director and the faculty supervisor, the students discussed the importance of the alumni-student relationship - a consideration that was underestimated by the students prior to this experience. An important takeaway for the students was that they needed Albion College alumni not only for scholarships but also for internship and job opportunities and leads as they move forward in their careers. Alumni need students to succeed because the college's reputation reflects on the value of their degrees. They are eager for current students to remain strong and have good opportunities.

\section{Conclusion}

The Association for American Colleges and Universities' report, Greater Expectations: A New Vision for Learning as a Nation Goes to College focused on ways to better prepare students for the twenty-first-century world: "Preparation for a fulfilling life, as well as a rewarding career, comprehends learning about the world, culture, and the arts" (Leskes 2002, 4). This sentiment is shared by the authors of this research and aligns with an approach to business education in a LAC environment, as evidenced by the undergraduate research experience featured in this article. The word business often connotes the negative stereotypes offered earlier, even among esteemed colleagues. However, a liberally educated undergraduate business studentone exposed to curricular, cocurricular, and experiential learning that fosters analytical thinking, multiple framing, and reflective exploration experiences - is exactly the type of aspiring business professional needed in the twenty-first century. For all these reasons, LACs can and should foster learning through undergraduate research experiences.

\section{References}

Baker, Vicki L., and Roger G. Baldwin. 2015. "A Case Study of Liberal Arts Colleges in the 21st Century: Understanding Organizational Change and Evolution in Higher Education." Innovative Higher Education 40: 247-261. doi.org/10.1007/ s10755-014-9311-6

Baker, Vicki L., Roger G. Baldwin, and Sumedha Makker. 2012. "Where Are They Now? Revisiting Breneman's Study of Liberal Arts Colleges." Liberal Education 98(3): 48-53.
Bartkus, Kenneth R. 2007. "Fostering Student/Faculty Collaborations through the Research Group Model: An Application to Colleges and Schools of Business." CUR Quarterly 28(2): 6-10.

Belkin, David. 2017. "Liberal Arts Colleges, in Fight for Survival, Focus on Job Skills." Wall Street Journal. April 24, 2017. www.wsj.com/articles/liberal-arts-colleges-in-fight-for-survivalfocus-on-job-skills-1493051024

Breneman, David W. 1990. "Are We Losing Our Liberal Arts Colleges?” AAHE Bulletin 43(2): 3-6.

Cavico, Frank J., and Bahaudin G. Mujtaba. 2009. "The State of Business Schools, Business Education, and Business Ethics." Journal of Academic and Business Ethics 2: 1-18.

Chickering, Arthur W., and Zelda F. Gamson. 1989. "Seven Principles for Good Practice in Undergraduate Education." Biochemical Education 17: 140-141. doi.org/10.1016/0307-4412(89)90094-0

Colby, Anne, Thomas Ehrlich, William M. Sullivan, and Jonathan R. Dolle. 2011. Rethinking Undergraduate Business Education: Liberal Learning for the Profession. San Francisco: Jossey-Bass.

Fairfield-Doering, Amy. 2013. "Project Springboard: Undergraduate Business Research as a Pathway to Innovation." CUR Quarterly 34(1): 10-14.

Fong, Bobby. 2004. "Looking Forward: Liberal Education in the 21st Century." Liberal Education 90(1): 8-13.

Friga, Paul N., Richard A. Bettis, and Robert S. Sullivan. 2003. "Changes in Graduate Management Education and New Business School Strategies for the 21st Century." Academy of Management Learning \& Education 2: 233-249. doi.org/10.5465/ amle.2003.10932123

Giacalone, Robert A. 2004. "A Transcendent Business Education for the 21st Century." Academy of Management Learning \& Education 3: 415-420. doi.org/10.5465/amle.2004.15112547

Guerriero Wilson, Robbie. 2015. "The Loss of Balance between the Art and Science of Management: Observations on the British Experience of Education for Management in the 20th Century." Journal of Management Education 39: 16-35. doi. org/10.1177/1052562914556314

Hensel, Nancy (Ed). 2012. Characteristics of Excellence in Undergraduate Research. Washington, DC: Council on Undergraduate Research.

Kuh, George D. 2008. High-Impact Educational Practices: What They Are, Who Has Access to Them, and Why They Matter. Washington, DC: Association of American Colleges and Universities.

Leskes, Andrea. 2002. Greater Expectations: A New Vision for Learning as a Nation Goes to College. Washington, DC: Association of American Colleges and Universities.

Miller, Barbara, and Steven DeLoach. 2016. "Letter from the Guest Editors." Perspectives on Undergraduate Research and Mentoring (PURM) 5.1. blogs.elon.edu/purm/2016/09/13/letterfrom-the-guest-editor-purm-5-1

Parker, Lee D., and James Guthrie. 2010. "Business Schools in an Age of Globalization." Accounting, Auditing \& Accountability Journal 23: 5-13. doi.org/10.1108/09513571011010583 
Raelin, Joseph A. 2016. "Work-Based (Not Classroom) Learning as the Apt Preparation for the Practice of Management." Management Teaching Review 1: 43-51.

doi.org/10.1177/2379298115617736

Starkey, Ken, and Nick Tiratsoo. 2007. The Business School and the Bottom Line. Cambridge: Cambridge University Press.

Wawrzynski, Korine Steinke. 2016. "Promoting Student Development through Undergraduate Research and Creative Activities" In Student Affairs for Academic Administrators, ed. T. Lynn Hogan, 92-102. Sterling, VA: Stylus.

\section{Vicki L. Baker}

Albion College, vbaker@albion.edu

Vicki L. Baker is a professor of economics and management at Albion College. Her research interests include faculty experiences and development, developmental networks, and liberal arts colleges. Baker earned her PhD in higher education administration from Pennsylvania State University.

John M. Carlson is an assistant professor of economics and management at Albion College. Carlson earned his $P h D$ in accounting at the University of Cincinnati.

\section{Coming up in SPUR...}

\section{Spring 2019 and Summer 2019:}

"Big Data as a Tool to Promote

Undergraduate Research"

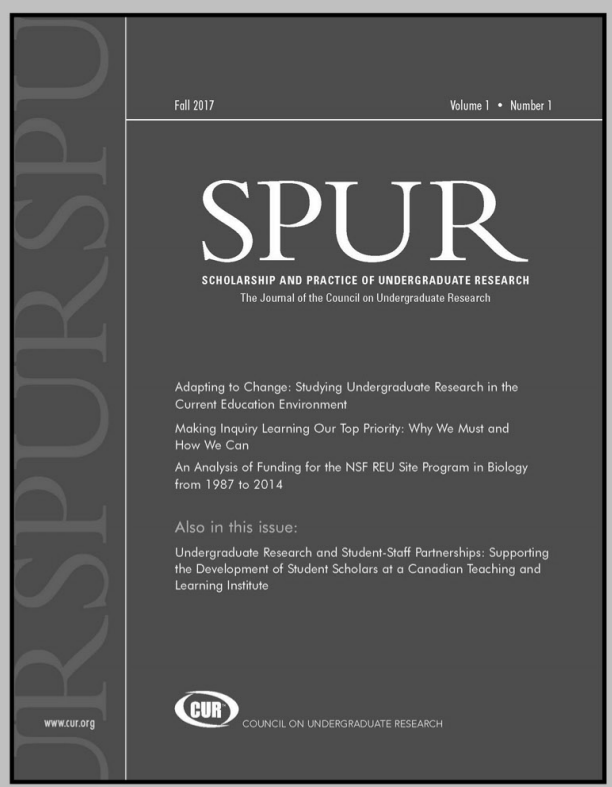

